\title{
How to Keep University Active during COVID-19 Pandemic: Experience from Slovakia
}

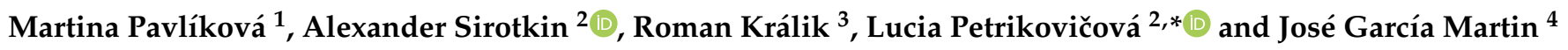 \\ 1 Faculty of Arts, Constantine the Philosopher University in Nitra, 94974 Nitra, Slovakia; mpavlikova@ukf.sk \\ 2 Faculty of Natural Sciences, Constantine the Philosopher University in Nitra, 94974 Nitra, Slovakia; \\ asirotkin@ukf.sk \\ 3 Department of Russian Language, Peoples' Friendship University of Russia (RUDN University), \\ 117198 Moscow, Russia; kierkegaaard@centrum.cz \\ 4 Department of Sociology, Faculty of Political Science and Sociology, University of Granada, \\ 18001 Granada, Spain; jgarciamartin@ugr.es \\ * Correspondence: lpetrikovicova@ukf.sk; Tel.: +421-907-344-104
}

\section{check for} updates

Citation: Pavlíková, M.; Sirotkin, A.; Králik, R.; Petrikovičová, L.; Martin, J.G. How to Keep University Active during COVID-19 Pandemic:

Experience from Slovakia.

Sustainability 2021, 13, 10350.

https://doi.org/10.3390/

su131810350

Academic Editors: Marc A. Rosen, Grigorios L. Kyriakopoulos and Antonio Messeni Petruzzelli

Received: 12 July 2021

Accepted: 9 September 2021

Published: 16 September 2021

Publisher's Note: MDPI stays neutral with regard to jurisdictional claims in published maps and institutional affiliations.

Copyright: (c) 2021 by the authors. Licensee MDPI, Basel, Switzerland. This article is an open access article distributed under the terms and conditions of the Creative Commons Attribution (CC BY) license (https:// creativecommons.org/licenses/by/ $4.0 /)$.

\begin{abstract}
The paper outlines the adverse consequences and challenges induced by COVID-19 pandemic for the whole world and for universities in particular. The example of Constantine the Philosopher University in Nitra illustrates the difficulties and challenges caused by the pandemic in relation to the two main activities arising from the university mission-teaching and research. It presents some particular aspects of the university activities adversely affected by COVID-19 and shares the measures to minimize the resulted damages. Furthermore, it demonstrates that, despite complications induced by COVID-19, teaching, research, and international cooperation have been successfully continued.
\end{abstract}

Keywords: COVID-19; Constantine the Philosopher University in Nitra (UKF); Erasmus+; international cooperation; research; teaching

\section{Introduction}

The pandemic of the novel coronavirus (COVID-19) is the world's largest pandemic in the last hundred years. At the time of writing this paper (beginning of 2021) the World Health Organization registers more than 90 million coronavirus cases and about 2 million deaths. The Czech and Slovak Republics have one of the highest growth rates of illnesses, resulted hospitalizations, and death in Europe [1].

This pandemic has, besides the adverse effect on health and mortality, enormous influence on all economic sectors-political, social, family, and personal life. Many branches of businesses (for example, international transport, culture, travel agencies, hotels, restaurants, some shops, and others) would have collapsed due to loss of their customers without state support [2].

The majority of countries around the world have used similar approaches to limit COVID-19 influence on the society [3], including:

1. Identification of persons contaminated by coronavirus by the development and application of a wide array of diagnostics, varying from temperature measurement up to detection of coronavirus by PCR tests.

2. Restriction of personal contacts to reduce chances of contamination among people, groups of people, areas, and countries (legislative limitation of population movement between countries and regions, and restriction, or full prohibition, of contacts in the working and leisure time or meeting points such as factories, offices, schools, restaurants, bars, discotheques, and others).

3. Measures for personal safety (keeping reasonable individual distance between people, wearing face masks and gloves, hand wash and disinfection, and others). 
4. Development and application of vaccines against COVID-19 and subsequent testing their safety and efficiency.

5. Education, information, and agitation of people to participate and support these measures.

6. Promotion of international solidarity and cooperation in the implementation of these measures.

The teaching process during COVID-19 is influenced by other factors: teaching methods, teaching principles, organizational forms of teaching, teaching aids, didactic techniques, and others. The term teaching process is meant as a planned, purposeful, and deliberate action of the subject of teaching (teacher) on the subject of training and education (student) to be systematically educated and brought up. During the teaching process, it is possible to observe several phases: motivational (preparation of students for active learning), exposure (initial acquaintance of students with the new curriculum), fixation (initial repetition and confirmation of the curriculum), and diagnostic (testing of acquired knowledge, skills, and habits). Research on the impact of a pandemic on education is currently addressed by several authors and institutions within their conditions, for example [4-11].

Usually, these measures are arranged by state or local authorities after voluntary agreement of the target population with a minimal impact on their personal rights. The rate, frequency, and intensity of the anti-COVID-19 measures introduced by state authorities, and the number of people involved, are usually proportional to the rate and frequency of COVID-19 contamination in particular regions, as well as the level of public education, information and disinformation about coronavirus, intensity, and accessibility of propaganda and contra-propaganda concerning anti-COVID-19 measures. The research question of our contribution is whether, and how, the pandemic affected the pedagogical process, and how it affected scientific research activities and individual mobility within the university.

\section{Methodology}

The article is focused on finding out the impact of a pandemic on individual activities of the university and its students and employees. We used the database and statistical data available to UKF. We used the statistical method to create tables in which we present the statistics of Erasmus mobility before the COVID-19 pandemic (academic years 2016/2017, $2017 / 2018$, and 2018/2019) and data from the academic year 2019/2020, when the pandemic was already taking place and continues today; it follows that, for the academic year 2020/2021, data are missing, respectively mobility has been completely stopped.

Part of the research was a questionnaire, by which we monitored attitudes to the impact of COVID-19 to their research, study, mobilities, work on projects, etc. in a sample of 500 students (100 students from each year of bachelor's and master's studies in the teaching study program) and 100 employees/teachers (mainly from the Faculty of Natural Sciences (70) and from the Faculty of Arts (30)). The aim of the questionnaire research was to find out how students evaluate the impact of a pandemic on their study activities (e.g., the way and methods of teaching in the online space, and social contact). In addition, we wanted to report the opinion of employees/teachers on whether their work activities are limited by a pandemic. We implemented the questionnaire in paper form and via the Internet. The types of groups were inhomogeneous, for example, by age and gender.

\section{Impact of COVID-19 on University Activities}

Each country establishes universities for two main purposes:

1. To provide higher education and training for top professionals in a country's industry, agriculture, science, culture, and local offices authorities, as well as for education experts at different school levels. University education includes not only professional education, but also ethical, language, communication, and sport training and development of the students' abilities, as well as their research skills.

2. To conduct basic and applied research, develop national and international science by recruiting university and out-of-university staff and university students, and ensuring 
scientific cooperation with national and international organizations (universities, research institutes, agencies, and other research bodies, industrial, agricultural, social, and other related organizations).

In this paper, we aim to share our personal experience related to the impact of COVID-19 on routine activities at Constantine the Philosopher University in Nitra (UKF), Slovakia. According to the information available from our partners in Slovakia and abroad, both the influence and consequences of pandemic were similar in other EU universities and the universities around the world. The differences between different universities and countries (if any) were rather quantitative than qualitative.

In Canada, for example, the University of Toronto tracks information for its community weekly by posting the number of confirmed COVID-19 cases among the members in the university. This is part of the university's commitment to maintaining a safe and healthy environment for its members to continue with tasks and to meet goals, and to help students and professors, and adapt to remote learning and teaching [12]. Similarly, the administration of UKF informs its staff about the pandemic situation at the university and distributes instructions related to various aspects of the university life on a weekly basis [13].

\subsection{COVID-19 Impact on Teaching}

Changes in the teaching process have usually been relevant to the stage of pandemic development.

At the first stage, when no cases of COVID-19 were detected at the university, the changes reflected the recommendations of the Ministry of Education and Ministry of Health Care concerning prophylactics of intrusion and distribution of virus infection among students, i.e., the most numerous part of academic community of the university. It was recommended to keep distance between students, to wear face masks, and to subject the lecture rooms to frequent cleaning, disinfection, and ventilation. No restriction in personal presence of both domestic students and teachers in lecture rooms or in student dormitories occurred. The measures and some restrictions affected mainly foreign students from so called "risk countries" [14].

The second stage was characterized by the occurrence of infected persons at the university. The first COVID-19 cases at the university were identified mainly among the foreign students from Serbia and Russia. A little later, a growing number of such cases were detected among domestic students and university staff. In this situation, both the Ministries and the university administration recommended to reduce personal presence of undergraduate and postgraduate students in university premises; to arrange lectures, seminars, laboratory works, tests, and exams online, if possible; and to prevent transmission of the virus contamination among students regardless of their country of origin [14]. Isolation of COVID-19 positive students was ensured with the separate parts of student dormitories and restriction of students' and teachers' mobilities with foreign universities; such mobilities were only allowed as an exception.

The third stage occurred during further pandemic development and massive occurrence of COVID-19 cases among the city inhabitants, as well as among students and university staff. At this stage, the university administration, in response to Ministries' measures and requirements, ordered:

1. prohibition of presence of all students in the premises of the university and in student's dormitories-it was suggested to both domestic and foreign students that they leave and stay at home;

2. obligatory online education for both undergraduate and postgraduate students;

3. cancellation of any mobilities of students and teachers with domestic and foreign universities;

4. restriction of $\mathrm{PhD}$ students and the university staff presence in the premises of the university. Such presence was allowed only for the key persons necessary for university governance, technical services, and the experimental studies which require 
personal presence of PhD students or scientists in the university offices/laboratories. These persons were obliged to follow measures towards personal safety (wearing face masks, personal distance, minimization of contacts with other persons, disinfection of hands and rooms, and others). Other employees were ordered to work from home (home-office). In some cases, these persons were provided with notebooks and other equipment necessary for the paperwork at home;

5. permission to enter the university building only to persons with negative results of either immunological or PCR test for COVID-19.

At the university, we conducted a basic questionnaire survey on the attitudes of students and staff regarding the impact of the pandemic on the teaching process, i.e., whether the pandemic affected their activities (Table 1). In total, 500 students and 100 teachers were contacted through an online questionnaire. Based on the answers from a sample of students and teachers, we can state that the pandemic did not affect the smooth running of teaching and scientific research. However, it has moved to online space.

Table 1. Attitudes to impact of COVID-19.

\begin{tabular}{|c|c|c|c|}
\hline \multirow{2}{*}{$\begin{array}{c}\text { Respondents/Acivity } \\
-\end{array}$} & \multicolumn{3}{|c|}{$\begin{array}{l}\text { Attitudes to Impact of COVID-19 to Their Research, Study, Mobilities, } \\
\text { Working on Projects, etc. }\end{array}$} \\
\hline & No $(\%$, abs.) & I Can't Judge (\%, abs.) & Yes (\%, abs.) \\
\hline Students (including lectures, mobilities) & $77(385)$ & $11.6(58)$ & $11.4(57)$ \\
\hline Employees - teachers (research, mobilities) & $60(60)$ & $20(20)$ & $20(20)$ \\
\hline
\end{tabular}

\subsection{COVID-19 Impact on Research}

Although the pandemic initially affected only interpersonal contacts and thus complicated teaching at the university, it also adversely affected the fulfillment of the second role of universities-the implementation of research activities of university staff. This effect was more evident in the third phase of development, when the COVID-19 pandemic reduced, complicated, or completely eliminated the following research activities:

1. Complication and in some cases even breaking off supply with material and consumables for research. For example, biology experts had to cancel biomedical experiments on rats, which should have been delivered from abroad, and in vitro experiments on organs, which they were receiving from slaughterhouses and hospitals, which stopped, restricted, or changed their ordinary activities due to the pandemic. Even the supply of books from abroad has been complicated and prolonged (for example, the publisher sent copies of a book from the US to its author in Slovakia via express delivery firm, which guaranteed their arrival within 3 days, but the deadline was not met; waiting time for their delivery has been prolonged for more than one month);

2. The pandemic also negatively affected domestic public transport and the hotel services-the number of transport connections was reduced, some bus and train lines and accommodation in hotels and student dormitories were cancelled. This greatly complicated travel and accommodation within our country, and thus the implementation of experiments and any personal contacts with university partners outside its location;

3. Research activities at the university headquarters were also complicated, as students and $\mathrm{PhD}$ students involved in carrying out this research lost their accommodation in student dormitories that were closed due to the pandemic. Therefore, in order to participate in research activities, experiments, and analyses on university premises, they had to look for alternative (private) accommodation;

4. The damage caused by the COVID-19 pandemic has also been evident at the level of international scientific cooperation. The pandemic has dramatically reduced or prevented international travel and border crossings, even within the EU. As a result of this situation, it was necessary to cancel personal participation in conferences, 
workshops, and other events, and scholarship study and research stays at foreign universities, even if they were previously planned, approved, and financially supported. If the implementation of research activities was agreed, and funds were allocated to them before the start of the pandemic, these activities had to be reduced or adjusted so that specific research activities and analyses could be carried out, not jointly, but separately, in domestic countries of universities isolated by COVID-19.

\subsection{COVID-19 Impact on UKF Cooperation with Embassy Representatives Accredited in Slovakia}

One of the most interesting and very beneficial activities in the framework of international relations of the UKF before the COVID-19 period was the cooperation with ambassadors accredited to Slovakia.

This cooperation has been implemented in several areas:

1. participation of ambassadors in important cultural and social events organized by UKF;

2. visits of ambassadors of various countries paid to the Rector of UKF followed by a lecture for students;

3. organization of socio-cultural activities and events by individual embassies on the university premises;

4. ambassadors' patronage of the university scientific events (conferences);

5. embassies assistance in establishing contacts and cooperation with the management of the relevant country's universities;

6. cooperation with ambassadors on international projects.

In 2018, the participation of 18 ambassadors in the inauguration of the Rector of UKF contributed to the unusual visibility of the university.

Among other activities and events, the following are worth mentioning:

1. Participation of Spanish Ambassador, H. E. Luis Belzuz de los Ríos, in an interesting event, Erasmus Village 2019, organized by UKF and Slovak University of Agriculture for foreign students;

2. Participation of the Ambassadors of Germany (H. E. Joachim Bleikert), Slovenia (H. E. Gregor Kozovinc) and Serbia (H. E. Momčilo Babič) in the international conference Religiosity, Spirituality and Alternative Religious Movements, organized by the Department of Religious Studies on 27 November 2019 at UKF in Nitra. The output was the proceedings of an international conference of Religiosity, Spirituality and Alternative Religious Movements Peter Kondrla (ed.) Nitra 2020 with interesting contributions;

3. Other interesting events were, for example, Canada-Day (Chargé d'Affaires John von Kaufmann), the Indonesian exhibition: Unity in Diversity (H. E. Adiyatwidi Adiwoso), the concert of the group Las Cuatro Estaciones (Ambassador of Chile, H. E. Gloria Navarette) and the traveling exhibition Strangers to Citizens organized on the university premises by the Ambassador of Ireland, H. E. Hildegard Ó Riain.

The most frequent visitors to the university were the Ambassadors of the Republic of Serbia, Germany, and Ireland. H. E. Igor Leshchenya (Belarus), H. E. Hatice Aslıgül Üğdül (the Republic of Turkey), H. E. Revaz Gachechiladze (Georgia), H. E. Minh Trong Duong (Vietnam), H. E. Yordanka Chovanova (Bulgaria), and H. E. Andrew Garth (Great Britain) introduced their countries in interesting lectures for students.

In establishing cooperation with foreign universities, excellent cooperation was with the Ambassador of China, H. E. Lin Lin, the Ambassador of Albania, H. E. Enkeleda Merkuri, the Ambassador of Argentina, H. E. Rafael Mariano Grossi and the Ambassador of the Hellenic Republic Greece, H. E. Maria Louisa Marinakis. Important visits that encouraged establishing further inter-university cooperation included visits by the Ambassadors of Israel, H. E. Boaz Modai and H. E. Zvi Vapni, [15], Belgium, H. E. Ghislain D'Hoop and Cuba, H. E. Yamila Sonia Pita Montes. In 2020, these activities were interrupted due to the pandemic COVID-19. 


\subsection{COVID-19 Impact on Academic Exchange along ERASMUS+}

Erasmus+ Mobilities

The Erasmus+ Program combines seven EU education, training, and youth programs including the university exchange program, formally known as the Erasmus Program.

The mobility component of the Erasmus+ KA103 program enables higher education students to study for part of their degree, or to pursue a traineeship, in a European or other associated country, encourages teacher and staff mobility for teaching or training, and promotes transnational cooperation projects among universities across Europe [2].

UKF has taken part in Erasmus+ KA103 mobilities since 1998. Currently, it has 434 Bilateral Agreements with universities in $27 \mathrm{EU}$ and EEA countries. Each academic year, more than 170 UKF students used to leave for a semester or two-semester stay in these universities, as well as 110 UKF staff for a week or two-week stay abroad. An inseparable part of this program is also incoming mobilities of students and staff from abroad. The most recent numbers of them were 49 students and 42 staff. The most popular destinations among UKF students were Spanish universities in Valencia and Almería, Portuguese universities in Porto and Coimbra, Czech universities in Prague and Hradec Králové, and Slovenian institutions in Ljubljana and Koper. The highest numbers of incoming students were from Spain (universities in Burgos and Las Palmas de Gran Canaria) and Portugal (universities in Porto and Funchal-Madeira).

Another mobility component of the Erasmus+ mobilities is Action KA107-mobility between program countries and partner countries, called International Credit Mobility (ICM). It is focused on mobility outside the EU countries. Since 2015, it enables the implementation of mobility of students and university staff. Mobilities between universities are based on prior signed mutual agreement of cooperation.

UKF has entered this Action since 2016 and its applications for grants have been highly successful. In the most recent application (2020), UKF applied for grants for countries with which its staff has demonstrated specific scientific and educational cooperation and interest to broaden the established links. Out of the 23 countries in the application, 19 have been given financial support, among them: Albania, Argentina, Bhutan, Canada, Chile, China, Cuba, Egypt, Georgia, Ghana, India, Iran, Israel, Mexico, Mongolia, Russian Federation, Tajikistan, Ukraine, and Uzbekistan [16]. Unfortunately, all the mobilities approved in the application have had to be delayed, though the International Office of the university is intensively working on signing Interuniversity Agreements so as to have all the documents ready after the pandemic is over.

The university monitors the situation in the countries concerned, but it still is too dangerous to send or welcome students and staff from them. For example, in Argentina, the first case of COVID-19 was detected on 2 March 2020 in the city of Buenos Aires. Immediately, the whole country went into total lockdown. From 27 April, the lockdown was territorially segmented, depending on the contagion level. The social isolation or social distancing established in Argentina measures were graded in five types: types 1-3 entail lockdown and isolation, while types $4-5$ suppose social distancing and normal activities. From October 2020, the cases began to decline progressively. However, a number of massive events over the end of the year, several political demonstrations, the celebration of the holidays, and the beginning of the summer vacations made the cases rise again. Additionally, a similar situation is in many other countries of the university's interest, including Slovakia.

For comparison, we present the numbers of mobility/Erasmus stays (KA103, KA107) before and during the pandemic. Even after the outbreak of the pandemic and the acceptance of restrictions, some students remained in their stay abroad and carried out their research and study online. On the basis of the statistics, we can conclude that no Erasmus stays were completely suspended during a pandemic (Tables 2 and 3). Statistical data for the academic year 2020/2021 are missing, respectively Erasmus mobility has not been realized. 
Table 2. The number of Erasmus mobility (before COVID-19).

\begin{tabular}{cccc}
\hline Erasmus Mobility & $\mathbf{2 0 1 6 / 2 0 1 7}$ & $\mathbf{2 0 1 7 / 2 0 1 8}$ & $\mathbf{2 0 1 8 / 2 0 1 9}$ \\
\hline Incoming student mobility & 26 & 35 & 44 \\
\hline Incoming employee mobility & 55 & 95 & 77 \\
\hline Outgoing student mobility & 156 & 145 & 182 \\
\hline Outgoing employee mobility & 96 & 131 & 165 \\
\hline
\end{tabular}

Table 3. Outgoing student mobility during COVID-19.

\begin{tabular}{cc}
\hline Erasmus Mobility & 2019/2020 \\
\hline $\begin{array}{c}\text { Outgoing student mobility during COVID-19 (affected by the mobility } \\
\text { pandemic) }\end{array}$ & 94 \\
\hline $\begin{array}{c}\text { Outgoing student mobility during COVID-19 (who stayed during a } \\
\text { pandemic on their Erasmus mobility) }\end{array}$ & 33 \\
\hline
\end{tabular}

\subsection{COVID-19 Impact on International Cooperation}

During the pandemic, the cooperation of UKF with institutions abroad has not changed its main aims and directions, but its forms have changed substantially. Personal contacts have been dramatically reduced, and they have been partially replaced by online contacts. Nevertheless, the international cooperation of UKF has not only been continued, but new partners have even been found, and fruitful collaboration with these partners has begun, some examples of such are listed below.

\subsubsection{Selected Examples of Interuniversity Cooperation}

The threats and challenges of the COVID-19 pandemic also influenced the promising cooperation with the renowned Kazan Federal University (KFU) in Kazan (Russia) and University of Mazandaran in Babolsar (Iran). UKF also included these universities among those that it applied for (and received) a financial grant from the Erasmus+ KA107 project for the development of cooperation. Initially, at the beginning of pandemic, it manifested itself in great uncertainty: What will follow? How to proceed?

Several UKF staff members were going to attend the International Forum on Teacher Education-IFTE-2020 - conference in Kazan in person, and KFU was starting negotiations on the admission of doctoral students for internships at UKF. However, in the situation of the COVID-19 pandemic, personal participation at conferences was not possible, and mobilities of students and staff were suspended. The question of what will follow has also become a major challenge for staff at the universities. New ways of cooperating and resolving the situation began to be sought. In a short time, KFU staff were very successful in turning the IFTE-2020 conference into a virtual one; all planned conference papers were presented online, and others were even added to the program of newly created conference sections which were the initiative of KFU staff. The presented conference papers of UKF staff were highly evaluated and subsequently published in databased journals [17].

As stated above, some papers were written in cooperation with the staff (Dr. Khonamri, Dr. Azizi) of University of Mazandaran in Babolsar (Iran), the cooperation with whom was the result of mutual visits of representatives from UKF at the University of Mazandaran, during which research and publication activities were agreed along with opportunities for the exchange of experience in the field of education.

The academic collaboration, when teaching could not be provided in person due to COVID-19 restrictions, has become another challenge. Teachers from Nitra and Babolsar came together online, and thus UKF students could listen to several lectures from Iran. Time was not an issue, as the time shift is only $2.5 \mathrm{~h}$. Publishing activities also have been, and are being, carried out in large numbers $[18,19]$, and mobility is being prepared in the belief that the pandemic is about to end. Despite COVID-19, international cooperation 
continued. On 16 December 2020, the Director of the Russian Center for Science and Culture in Bratislava, Mrs. Inna Kuznetsova, accompanied by the First Secretary of the Embassy of the Russian Federation in Slovakia, Mr. Vladislav Kulikov, visited UKF. The delegation was received by the Rector of UKF accompanied by the Vice-Rector for International Relations, and two representatives of the Faculty of Arts-Vice-Dean for International Relations and the head of the Department of Russian Language. The main topics of the meeting were the possibilities of organizing a photo exhibition of the State Literary Museum on the life and work of L. N. Tolstoy, the project of supporting the translation school, and the possibility of establishing and opening the Center "Russkij Mir" on the premises of UKF [20].

\subsubsection{Selected Examples of Interuniversity Cooperation}

Even before the COVID-19 pandemic, cooperation between the Embassy of Ireland in Slovakia and the Department of Translation Studies, UKF, began successfully. Following the decision of the embassy to organize the exhibition Strangers to Citizens in the premises of UKF, the department showed initiative and willingness to translate its students' texts for individual posters of the exhibition. The translations of approximately 20 first- and second-year master's students in translation were coordinated by Prof. Edita Gromová, Prof. Dáša Munková and Dr. Katarína Welnitzová. The ambassador was very pleased with this cooperation, and considered it very useful for the visitors of the exhibition. Based on this cooperation, the ambassador subsequently offered the department to take over the guarantee of organizing the Young Translator 2019 competition, which is intended for upper secondary school students who are interested in studying translation. In connection with this competition, she selected texts for translation that contained information about Ireland, its interesting cities and places, the history and culture of Ireland, its festivals and films, Irish cuisine, sports, and others [21].

Another student activity is the involvement of students from two UKF facultiesFaculty of Arts (Department of Translation Studies and Department of Culture and Tourism Management) and Faculty of Natural Sciences (Department of Chemistry) - in international cooperation with Financial University under the Government of the Russian Federation in Moscow via joint students' scientific project Academic Environment in Terms of Global Digitalization. The main aim of the project is to develop international students' scientific collaboration and implement the results of the joint scientific work in academic environment of the universities. The cooperation with the Financial University has been initiated by the Vice-rector for International Relations [22].

\subsubsection{Selected Publication Outputs of UKF Staff with Foreign Researchers}

Cooperation with scientists from Russia during the pandemic in 2020 also brought interesting outputs in the publishing house Springer Nature [23,24]. Publications created on the basis of cooperation with Iranian scientists have been published in several databased journals [25-28]. The philosopher, Assoc. Prof. P. Kondrla has been collaborating on studies with Russian and Czech scientists for a long time [29-32]. Professor Jana Duchovicova is an expert in education sciences and teacher training, and is developing cooperation with Kazan Federal University [33]. UKF also has long-term cooperation with Spanish scientists; joint studies have been published, for example, on Danish philosopher S. Kierkegaard and his work [34], refugees' acquisition of L2 [35], and on topics related to natural sciences [36-38]. The cooperation between UFK and Spanish Kierkegaardian researchers goes back a long way, Specifically, since 2008 (Kierkegaard and Faith, Barcelona: University of Barcelona), more specifically with Dr. José García Martín (University of Granada) and the Kierkegaardian society he presides (Sociedad Hispánica de Amigos de Kierkegaard). This collaboration has been manifested through various means: seminars, international conferences, articles, books, and Erasmus or research stays. In this sense, we could highlight the following collaborations (apart from the one mentioned above): (a) book Persona y sociedad/Person and Society, Toronto: Kierkegaard Circle, Trinity College, University of Toronto, 2014; (b) different Seminars on Kierkegaard (2012 and 
following years) in the Faculty of CC. PP. and Sociology of the University of Granada; (c) articles such as The Problem of the "Individual" Concept in the Kierkegaard's Journals (European Journal of Science and Theology, April 2020, Vol. 16, No. 2, 39-46), or The Kantian ethical perspective seen from the existential philosophy of Søren Kierkegaard's Victor Eremita (Ethics \& Bioethics, June 2021, 11 (1-2), 48-57); and (d) several Erasmus or research stays over almost a decade (2012-2019), both from Slovakia (in the person of Professor Dr. Roman Králik or other colleagues), and Spain (in the person of Dr. José García Martín, who received, with the award of a prize in the European Journal of Science and Theology, Vol. 16, No. 2). José García Martín, who received the FF UFK commemorative medal from the hand of the dean (Zdenka Gadušová in 2010), as a reward for his decisive contribution to international Kierkegaardian research; likewise, the visit of the Vice-Rector for International Relations of the UFK, Martina Pavliková, to the University of Granada, from which a collaboration between both universities was formally established, should be noted. Biologist, Prof. Alexander Sirotkin, has a long history of working with scientists from Saudi Arabia [39,40]. Cooperation with Czech scholars and scientists is also very fruitful: Prof. František Petrovič has been developing cooperation in the field of environmental sciences [41,42]; they are experts in Geography and cooperate in the field of services [43]; as well as Assoc. Prof. Anton Trník in the field of physics [44], and biology [45]. Assoc. prof. Matej Vojtek has established cooperation in the area of hydrological modelling with Indian and Italian scientists [46]. The most active scholar from Faculty of Education (UKF) is Prof. Alena Hašková $[47,48]$. Prof. Michal Munk from the Faculty of Natural Sciences is also internationally active: [49]. The cooperation with CONICET-UBA, Buenos Aires (Argentina) is also very inspiring. The result is a number of common publication outputs in databases: [50,51]. In 2020, significant international cooperation was also developed with scientists from Turkey, Bulgaria, and Poland [52-54]. Interesting cooperation with concrete results has taken place in recent years between UKF and the College of Applied Psychology in Terezin (Czech Republic). The cooperation started thanks to doc. Peter Kondrla, PhD. UKF and doc. Patrik Maturkanič, in 2017 in the field of religious studies, which resulted in joint project: Pastoral practice, psychology and philosophical-theological-social fragments in the light of the 21st century (with coordinator: Prof. José García Martin, ID agreement 16255199) and continued in other publishing results [55-58].

\subsubsection{International Conferences}

Researchers regularly attend international conferences. Among the most interesting and recorded in the WOS databases are the annual conferences ICERI, EDULEARN, and INTED in Spain. In 2020, from among the most interesting and valuable papers from these conferences can be mentioned: [59-66].

As to international conferences, a significant event was the second Central European Symposium on Thermophysics conference in Eger (Hungary), in which physics scholars took part. The output was interesting studies: $[67,68]$. The scholars from the Faculty of Central European Studies (UKF) participated in the tenth International Conference: The Future of Education-Virtual Edition, which was held in Florence (Italy) [69] and in the International Academic Conference: Education and Social Sciences, Business and Economics held in Belgrad (Serbia) [70-72].

The cooperation, which was started by Dr. Lucia Petrikovičová from the Department of Geography and Regional Development (Faculty of Natural Sciences, UKF) is developing in the international conference QS Subject Focus Summit-Modern Languages and Linguistics, held in Moscow in December 2020, and organized by Peoples' Friendship University of Russia, was also important, as the conference was attended by representatives from 50 countries from all continents [73] and joint scientific publications have been published [74-77]. Under the leadership of Dr. Lucia Petrikovičová, a scientific project proposal is currently being prepared, which concerns "Quality of Life" and is the result of cooperation between RUDN in Moscow and UKF in Nitra. This cooperation is supported by the leadership of both universities. Important and long-term cooperation is taking place 
with scientists from Slovenia [78,79]. Employees of FF UKF in Nitra (Assoc. Prof. Kondrla, Dr. Pavlikova, and Professor Roman Králik) have long participated in the conference organized by Dr. Primož Repar (KUD APOKALIPSA a CERI-SK Ljubljana). In the period from 2019 to 2021, the cooperation focused only on joint scientific publications [80-83].

Among the domestic conferences held in Nitra, it is worth mentioning the 28th International Geographical Conference: Geographical Aspects of Central Europe-Creativity of Regions. It was organized by the Department of Geography and Regional Development (Faculty of Natural Sciences, UKF) in cooperation with the Department of Geography (Masaryk University in Brno, Czech Republic), the Department of Tourism (Faculty of Central European Studies, UKF), and Western Slovakia Branch of Slovak Geographical Society on 14 October 2020. The conference was virtual, due to the unsuitable epidemiological situation [84].

\section{Conclusions}

The experience outlined above shows that the COVID-19 pandemic has adversely affected all aspects of university work: teaching, research, national and international cooperation in teaching and research, and the lives of university teachers and students. The problems caused by the COVID-19 pandemic at UKF reflect similar problems that all universities around the world face today. The example of the UKF merely illustrates the damage caused by a coronavirus pandemic in all areas of university life and international cooperation among universities around the world. Despite the difficulties of personal communication between the people of the academic community, however, not only teaching and research continued, but also fruitful international cooperation. Not only are international cooperation projects agreed before the COVID-19 pandemic continued, but UKF has also acquired new international academic partners, and new international cooperation projects have begun. The continuation of this cooperation is illustrated by UKF's contacts with ambassadors, the participation of UKF experts in international conferences, and numerous joint scientific publications. Vaccination against COVID-19 is a hope to return to normal life at universities and the economy as a whole. More about COVID and UKF can be found in $[85,86]$.

Based on a questionnaire survey of students and teachers, we can state that the pandemic did not affect the smooth running of teaching and scientific research. However, it has moved to online space. Even after the outbreak of the pandemic and the acceptance of restrictions, some students remained in their stay abroad and carried out their research and study online. On the basis of the statistics, we can conclude that any Erasmus stays were completely suspended during a pandemic. We can state that the numbers of Erasmus mobilities (KA103, KA107) have not decreased compared to the years before the pandemic.

The presented materials do not represent the list of achievements of our university or the reports concerning its activities in particular areas, but rather the demonstration that, even in conditions of pandemics, the main activities of the university (if some antipandemic measures could be efficient) could be retained and even developed. The main implication and the main conclusion of this research is the fact that, even in conditions of pandemics which complicate all the activities of the university, the basic activities such as teaching, research, and cooperation could be retained, continued, and even developed.

Author Contributions: Conceptualization, M.P., A.S., R.K. and L.P.; methodology, M.P., A.S. and R.K.; validation, M.P., A.S. and L.P.; formal analysis, A.S.; investigation, M.P. and R.K.; resources, L.P. and J.G.M.; data curation, A.S., M.P. and R.K.; writing-original draft preparation, M.P., A.S., R.K., L.P. and J.G.M.; writing-review and editing, R.K.; visualization, L.P.; and supervision, A.S. All authors have read and agreed to the published version of the manuscript.

Funding: This article was published with the support of the Slovak Research and Development Agency under the contract No. APVV-17-0158. This paper was supported also by Scientific Grant Agency VEGA project No 1/0880/21 “Transformation of the Nitra Region in Changing Socioeconomic Conditions with Special Focus to the Effects of the COVID-19 Pandemics". 
Institutional Review Board Statement: Not applicable.

Informed Consent Statement: Not applicable.

Data Availability Statement: Not applicable.

Conflicts of Interest: The authors declare no conflict of interest.

\section{References}

1. COVID 19. Available online: https:/ / covid19.who.int/ (accessed on 9 July 2021).

2. Europa. Available online: https:/ / ec.europa.eu?eurostat?web/covid-19/economy (accessed on 9 July 2021).

3. Consilium. Available online: http:/ / www.consilium.europa.eu/policies/coronavirus/10-things-against-covid-19 (accessed on 9 July 2021).

4. Blackledge, J. Thoughts on the Future of Higher Education in the UK: A Personal View with a Historical Context. Educ. Sci. 2021, 11, 474. [CrossRef]

5. Khandan, R.; Shannon, L. The Effect of Teaching-Learning Environments on Student's Engagement with Lean Mindset. Educ. Sci. 2021, 11, 466. [CrossRef]

6. Alhammadi, S. The Effect of the COVID-19 Pandemic on Learning Quality and Practices in Higher Education-Using Deep and Surface Approaches. Educ. Sci. 2021, 11, 462. [CrossRef]

7. Hakami, Z. Comparison between Virtual and Traditional Learning Methods for Orthodontic Knowledge and Skills in Dental Students: A Quasi-Experimental Study. Healthcare 2021, 9, 1092. [CrossRef]

8. Al-Adwan, A.S.; Albelbisi, N.A.; Huiran, O.; Al-Rahmi, W.M.; Alkhalifah, A. Developing a Holistic Success Model for Sustainable E-Learning: A Structural Equation Modeling Approach. Sustainability 2021, 13, 9453. [CrossRef]

9. Estriegana, R.; Medina-Merodio, J.-A.; Robina-Ramírez, R.; Barchino, R. Analysis of Cooperative Skills Development through Relational Coordination in a Gamified Online Learning Environment. Electronics 2021, 10, 2032. [CrossRef]

10. Januszewski, A.; Grzeszczak, M. Internship of Accounting Students in the Form of E-Learning: Insights from Poland. Educ. Sci. 2021, 11, 447. [CrossRef]

11. Tsang, J.T.Y.; So, M.K.P.; Chong, A.C.Y.; Lam, B.S.Y.; Chu, A.M.Y. Higher Education during the Pandemic: The Predictive Factors of Learning Effectiveness in COVID-19 Online Learning. Educ. Sci. 2021, 11, 446. [CrossRef]

12. Utoronto. Available online: https:/ / www.utoronto.ca/utogether/covid19-dashboard (accessed on 9 July 2021).

13. Univerzita Konštantína Filozofa. Available online: https:/ /www.ukf.sk (accessed on 9 July 2021).

14. Univerzita Konštantína Filozofa. Available online: https://www.ukf.sk/en/public-relations/news/events/4103-accommodationfor-students-from-covid-19-high-risk-countries) (accessed on 9 July 2021).

15. Králik, R. Justice and Memory—Story about Eichmann and Argentina. Eur. J. Sci. Theol. 2020, 16, 1-3.

16. Univerzita Konštantína Filozofa. Available online: https://www.ukf.sk/en/public-relations/news/events/3991-successfulerasmus-ka107-application (accessed on 8 June 2021).

17. Stranovská, E.; Gadušová, Z. Learners' Success and Self-esteem in Foreign Language Reading Comprehension. Educ. Self Dev. 2020, 15, 109-119. [CrossRef]

18. Khonamri, F.; Pavlíková, M. Exploring Teachers' and Learners' Attitude towards Homework: The case of English versus Non-English-Major Teachers' Homework Practices. Educ. Self Dev. 2020, 15, 32-49. [CrossRef]

19. Azizi, M.; Pavlíková, M.; Slováková Nováková, K.; Baghana, J. The Differential Effects of Dynamic Assessment versus Coded Focused Feedback on the Process Writing of EFL Learners. Eur. J. Contemp. Educ. 2021, 10, 273-284. [CrossRef]

20. Univerzita Konštantína Filozofa. Available online: https://www.ukf.sk/verejnost/aktuality/udalosti/4426-navsteva-z-ruskehocentra-vedy-a-kultury (accessed on 8 June 2021).

21. Univerzita Konštantína Filozofa. Available online: https://www.ukf.sk/en/public-relations/news/events/3931-ukf-s-studentstranslated-about-ireland/ (accessed on 8 June 2021).

22. Univerzita Konštantína Filozofa. Available online: https://www.ukf.sk/en/public-relations/news/events/4433-internationalcooperation-with-russia (accessed on 8 June 2021).

23. Kozharinov, A.V.; Kalugina, O.A.; Ryabchenko, N.V.; Kolobkova, A.A.; Králik, R. Innovative methods of mastering economic knowledge by learning a foreign language. Stud. Syst. Decis. Control 2021, 316, 615-623. [CrossRef]

24. Maksaev, A.A.; Vasbieva, D.G.; Sherbakova, O.Y.; Mirzoeva, F.R.; Králik, R. Education at a cooperative university in the digital economy. Stud. Syst. Decis. Control 2021, 316, 33-42.

25. Azizi, M.; Tkáčová, H.; Pavliková, M.; Jenisová, Z. Extensive Reading and the Writing Ability of EFL Learners: The Effect of Group Work. Eur. J. Contemp. Educ. 2020, 9, 726-739. [CrossRef]

26. Azizi, M.; Králik, R.; Petrikovičová, L.; Tkáčová, H. A comparative study of the effects of self-assessment and peer feedback on literature students' oral production. Sci. Educ. Today 2020, 10, 10-27. [CrossRef]

27. Khonamri, F.; Ahmadi, F.; Pavlíková, M.; Petrikovicova, L. The Effect of Awareness Raising and Explicit Collocation Instruction on Writing Fluency of EFL Learners. Eur. J. Contemp. Educ. 2020, 9, 786-806. [CrossRef]

28. Khonamri, F.; Pavlíková, M.; Falahati, M.; Petrikovičová, L. Investigating the Co-Development of Reading Fluency and Reading Comprehension through Mindfull Teaching of Collocations in EFL Classrom. Sci. Educ. Today 2020, 10, 7-27. [CrossRef] 
29. Máhrik, T.; Vasbieva, D.G.; Králik, R.; Kondrla, P. Salvation as the teleological vector in Kierkegaard's practice in Christianity. Eur. J. Sci. Theol. 2020, 16, 43-52.

30. Vymětalová Hrabáková, E.; Kondrla, P.; Vlasova, K.; Dmitrichenkova, S.V.; Pashanova, O.V. Human as the protector of creation. Xlinguae 2020, 13, 13-21. [CrossRef]

31. Roubalová, M.; Kalugina, O.; Králik, R.; Kondrla, P. The end of the Kingdom of Judah and its echoes in the Jewish calendar. Xlinguae 2020, 13, 194-205. [CrossRef]

32. Roubalová, M.; Králik, R.; Kondrla, P. Importance and method of teaching Biblical Hebrew and Aramaic in religious education of children and adults. J. Educ. Cult. Soc. 2021, 12, 59-67. [CrossRef]

33. Duchovičová, J.; Kováčiková, E.; Khuziakhmetov, A.N.; Valeev, A.A. Phonematic Awareness and Chosen Cognitive Functions of a Child. Eur. J. Contemp. Educ. 2019, 8, 751-760. [CrossRef]

34. Martin, J.M.; Morales, R.A.; Králik, R. The problem of the 'individual' concept in the Kierkegaard's journals. Eur. J. Sci. Theol. 2020, 16, 39-46.

35. Cobo, M.O.; Králik, R.; Bianco, R. Refugees' L2 learning: New perspectives on language motivation research. XLinguae 2020, 13, 64-80. [CrossRef]

36. Sirotkin, A.V.; Radosová, M.; Tarko, A.; Martín-García, I.; Alonso, F. Effect of morphology and support of copper nanoparticles on basic ovarian granulosa cell functions. Nanotoxicology 2020, 14, 683-695. [CrossRef] [PubMed]

37. Medová, J.; Bulková, K.O.; Čeretková, S. Relations between Generalization, Reasoning and Combinatorial Thinking in Solving Mathematical Open-Ended Problems within Mathematical Contest. Mathematics 2020, 8, 2257. [CrossRef]

38. Kolena, B.; Petrovičová, I.; Šidlovská, M.; Hlisníková, H.; Bystričanová, L.; Wimmerová, S.; Trnovec, T. Occupational Hazards and Risks Associated with Phthalates among Slovakian Firefighters. Int. J. Environ. Res. Public Health 2020, 17, 2483. [CrossRef] [PubMed]

39. Aldawood, N.; Alrezaki, A.; Alanaza, S.; Amir, N.; Alwasel, S.; Sirotkin, A.; Harrath, A.H. Acrylamide impairs ovarian function by promoting apoptosis and affecting reproductive hormone release, steroidogenesis and autophagy-related genes: An in vivo study. Ecotoxicol. Environ. Saf. 2020, 197, 10595. [CrossRef]

40. Sirotkin, A.V.; Tarko, A.; Kotwica, J.; Alrezaki, A.; Harrath, A.H. Interrelationships between metabolic hormones, leptin and ghrelin, and oil-related contaminants in control of oxytocin and prostaglandin Frelease by feline ovaries. Reprod. Biol. 2020, 20, 254-258. [CrossRef]

41. Falt’an, V.; Katina, S.; Minár, J.; Polčák, N.; Bánovský, M.; Maretta, M.; Zámečník, S.; Petrovič, F. Evaluation of Abiotic Controls on Windthrow Disturbance Using a Generalized Additive Model: A Case Study of the Tatra National Park, Slovakia. Forests 2020, 11, 1259. [CrossRef]

42. Grežo, H.; Misovicova, R.; Pucherová, Z.; Petrovič, F. Free and open source software and data for good and bad times. In Proceedings of the EDULEARN 2020: 12th International Conference on Education and New Learning Technologies, Online, 6-7 July 2020; IATED Academy: Palma de Mallorca, Spain, 2020; pp. 6090-6094.

43. Vilinová, K. Spatial Autocorrelation of Breast and Prostate Cancer in Slovakia. Int. J. Environ. Res. Public Health 2020, 17, 4440. [CrossRef]

44. Húlan, T.; Štubňa, I.; Trník, A.; Vozár, L. Firing of illite-basted ceramics followed by dynamical thermomechanical analysis. AIP Conf. Proc. 2020, 2275, 020008.

45. Borkovcová, M.; Fišer, V.; Bednárová, M.; Havlíček, Z.; Adámková, A.; Mlček, J.; Juríková, T.; Balla, Š.; Adámek, M. Effect of Accumulation of Heavy Metals in the Red Fox Intestine on the Prevalence of Its Intestinal Parasites. Animals 2020, 10, 343. [CrossRef] [PubMed]

46. Costache, R.; Pham, Q.B.; Sharifi, E.; Linh, N.T.T.; Abba, S.I.; Vojtek, M.; Vojteková, J.; Nhi, P.T.T.; Khoi, D.N. Flash-Flood Susceptibility Assessment Using Multi-Criteria Decision Making and Machine Learning Supported by Remote Sensing and GIS Techniques. Remote Sens. 2020, 12, 106. [CrossRef]

47. Kuna, P.; Hašková, A.; Mukhashavria, S. Application of virtual reality in industrial control systems. In Proceedings of the DIVAI 2020: 13th International Scientific Conference on Distance Learning in Applied Informatics, Online, Štúrovo, Slovakia, 21-23 September 2020; Wolters Kluwer: Praha, Czech Republic, 2020; pp. 139-148.

48. Zahorec, J.; Hašková, A. Pre-gradual teacher training in the area of didactic technological competencies. In Proceedings of the ERIE 2020: Proceedings of the 17th International Conference Efficiency and Responsibility in Education, Prague, Czech Republic, 4-5 June 2020; Czech University of Life Sciences: Praha, Czech Republic, 2020; pp. 332-338.

49. Munková, D.; Munk, M.; Skalka, J.; Kasaš, K. Automatic Evaluation of MT Output and Post-edited MT Output for Genealogically Related Languages. In Proceedings of the EMENA-ISTL 2019, International Conference Europe Middle East \& North Africa on Information System Technology and Learning Researches, Marrakech, Morocco, 21-23 November 2019; Springer: Cham, Switzerland, 2019; pp. 416-425.

50. Brusco, P.; Vidal, J.; Beňuš, Š.; Gravano, A. A cross-linguistic analysis of the temporal dynamics of turn-taking cues using machine learning as a descriptive tool. Speech Commun. 2020, 125, 24-40. [CrossRef]

51. Binetti, M.; Králik, R.; Tkáčová, H.; Roubalová, M. Same and Other: From Plato to Kierkegaard. A reading of a metaphysical thesis in an existential key. J. Educ. Cult. Soc. 2021, 12, 15-31. [CrossRef] 
52. Juríková, T.; Mlček, J.; Žitná, M.; Hlaváčová, I.; Dokoupil, L.; Sochor, J.; Ercisli, S.; Ozkan, G. Fruit maturity stage in relation to content of polyphenols, flavonoids and antioxidant activity of selected clones of Lonicera kamtschatica (Sevast.) Pojark. Genetika 2020, 52, 881-893. [CrossRef]

53. Bozhuyuk, M.R.; Ercisli, S.; Ayed, R.B.; Jurikova, T.; Fidan, H.; Ilhan, G.; Ozkan, G.; Sagbas, H.I. Compositional diversity in fruits of rowanberry (Sorbus aucuparia L.) genotypes originating from seeds. Genetika 2020, 52, 55-65. [CrossRef]

54. Martiniakova, M.; Sarocka, A.; Kovacova, V.; Kapusta, E.; Goc, Z.; Gren, A.; Formicki, G.; Omelka, R. Antagonistic Impact of Acrylamide and Ethanol on Biochemical and Morphological Parameters Consistent with Bone Health in Mice. Animals 2020, 10, 1835. [CrossRef]

55. Čerget'ová-Tomanová, I.; Maturkanič, P.; Hlad, L'.; Biryuková, Y.N.; Martin, J.G. Spirituality and Irrational beliefs of movement activities in Slovaks and Czechs. J. Educ. Cult. Soc. 2021, 12, 539-549.

56. Maturkanič, P.; Čerget'ová-Tomanová, I.; Kondrla, P.; Kurilenko, V.; Martin, J.G. Homo culturalis versus Cultura animi. J. Educ. Cult. Soc. 2021, 12, 51-58.

57. Hlad, L'. Paul Strauss and his Philosophical-Religious Interpretation of the Phenomenon of Dying, Death and Psychical-Physical Suffering. In Spiritual and Social Experience in the Context of Modernism and Postmodernism: (Interdisciplinary Reading of the Phenomenon); Lulu Publishing Company: Morrisville, NC, USA, 2021; pp. 341-363.

58. Hlad, L'. Psychological and Spiritual Dimension of the Disease in Optics of the Experience of Paul Strauss I. Appl. Psychol. 2021, 9, 752-762.

59. Tureková, I.; Hašková, A.; Marková, I.; Bilčíková, J. Activating methods and their use in online education. In Proceedings of the ICERI 2020: Proceedings of the 13th International Conference of Education, Research and Innovation, Seville, Spain, 9-11 November 2020; IATED Academy: Seville, Spain, 2020; pp. 9947-9953. [CrossRef]

60. Lalinská, M.; Stranovská, E.; Gadušová, Z. Measurement of reading comprehension in second foreign language. In Proceedings of the INTED 2020: 14th annual International Technology, Education and Development Conference, Valencia, Spain, 2-4 March 2020; IATED Academy: Valencia, Spain, 2020; pp. 5018-5026. [CrossRef]

61. Vilinová, K.; Petrikovičová, L. Implementation of Inquiry-based Activities in the Teaching Process of Geography. In Proceedings of the ICERI 2020: 13th International Conference of Education, Research and Innovation, Seville, Spain, 9-11 November 2020; IATED Academy: Valencia, Spain, 2020; pp. 1230-1237. [CrossRef]

62. Welnitzová, K.; Munková, D. Evaluation and self-evaluation in trainees' performances in translation studies training. In Proceedings of the INTED 2020: 14th Annual International Technology, Education and Development Conference, Valencia, Spain, 2-4 March 2020; IATED Academy: Valencia, Spain, 2020; pp. 8364-8372. [CrossRef]

63. Kondrla, P.; Tvrdoň, M.; Tkáčová, H. Current challenges for social work: Stereotyping as an obstacle to the integration of marginalized groups into society. In Proceedings of the ICERI 2020: Proceedings of the 13th International Conference of Education, Research and Innovation, Seville, Spain, 9-11 November 2020; IATED Academy: Seville, Spain, 2020; pp. 3837-3843. [CrossRef]

64. Kondrla, P.; Tkáčová, H.; Tvrdoň, M. Social work and its impact on alleviating the social exclusion of religious minorities. In Proceedings of the ICERI 2020: Proceedings of the 13th International Conference of Education, Research and Innovation, Seville, Spain, 9-11 November 2020; IATED Academy: Seville, Spain, 2020; pp. 3844-3851. [CrossRef]

65. Bárcziová, Ž. Hungarian minority literature in the Slovak educational system. In Proceedings of the INTED 2020: 14th Annual International Technology, Education and Development Conference, Valencia, Spain, 2-4 March 2020; IATED Academy: Valencia, Spain, 2020; pp. 3786-3791. [CrossRef]

66. Tvrdoň, M. Equal opportunities-Comparison of ethical education and religious education curriculam. In Proceedings of the INTED 2020: 14th Annual International Technology, Education and Development Conference, Valencia, Spain, 2-4 March 2020; IATED Academy: Valencia, Spain, 2020; pp. 5517-5523. [CrossRef]

67. Al-Shantir, O.; Keppert, M.; Vrabec, M.; Trník, A. Influence of compression pressure on thermal expansion, bulk density, and porosity of electroporcelain after firing. AIP Conf. Proc. 2020, 2275, 020001. [CrossRef]

68. Húlan, T.; Štubňa, I.; Ondruška, J.; Csáki, Š.; Lukáč, F.; Mánik, M.; Vozár, L.; Ozolins, J.; Kaljuvee, T.; Trník, A. Young's Modulus of Different Illitic Clays during Heating and Cooling Stage of Firing. Materials 2020, 13, 4968. [CrossRef]

69. Beták, N.; Sándorová, Z. The Creativity of Tourism Undergraduates as Future Creative Tourism Experts; Filodiritto Publisher: Florence, Italy, 2020; pp. 271-275. (Online)

70. Beták, N. The Use of Active Learning Approach in Tourism Education: Pilot Study of Students Attitude. In The 2020 IAI Book of Proceedings: Education and Social Sciences, Business and Economics, 02.03.2020; International Academic Institute: Beograd, Serbia; Skopje, North Macedonia, 2020; pp. 70-78. ISBN 978-608-4881-08-7.

71. Martín, J.G.; Rojas, A.M.; Králik, R. The Kantian ethical perspective seen from the existential philosophy of Søren Kierkegaard's Victor Eremita. Ethics Bioeth. (Cent. Eur.) 2021, 11, 48-57. [CrossRef]

72. Ambrozy, M.; Králik, R.; Martín, J.G. Determinism vs freedom: Some ethics-social implications. XLinguage 2017, 10, 48-57. [CrossRef]

73. Univerzita Konštantína Filozofa. Available online: https://www.ukf.sk/en/public-relations/news/events/4428-representativeof-fns-UKF-at-an-international-conference-in-moscow (accessed on 8 June 2021).

74. Knonamri, F.; Kralik, R.; Vitečkova, M.; Petrikovičová, L. Self-Assessment and EFL Literature Students' Oral Reproduction of Short Stories. Eur. J. Contemp. Educ. 2021, 10, 77-88. 
75. Petrikovičová, L.; Ďurinková, A.; Králik, R.; Kurilenko, V. Methodology of Working with a Textbook versus Field Activities of Teaching Geography during the Corona Crisis. Eur. J. Contemp. Educ. 2021, 10, 428-437.

76. Petrikovičová, L.; Dysková, S.; Pavlíková, M.; Vasbieva, D.G.; Kalugina, O.A. Teaching Geographical Methods and Forms in The United States, Iceland and Slovakia. AD ALTA J. Interdiscip. Res. 2021, 11, 398. [CrossRef]

77. Dysková, S.; Petrikovičová, L.; Roubalová, M. The Growth of Tourism and Its Impact on the Protected Areas of Iceland. AD ALTA J. Interdiscip. Res. 2021, 11, 402. [CrossRef]

78. Kondrla, P.; Repar, P. Ontological consequences of the ethics of technology Communications. Sci. Lett. Univ. Zilina 2017, 19, 19-24.

79. Kondrla, P.; Repar, P. Postmodern aspects of new religious movements. Eur. J. Sci. Theol. 2017, 13, 67-74.

80. Žalec, B.; Pavlíková, M. Religious tolerance and intolerance. Eur. J. Sci. Theol. 2019, 15, 39-48.

81. Pavlíková, M.; Žalec, B. Struggle for the human self and authenticity: Kierkegaard's critique of the public, established order, media, and false christianity. Bogosl. Vestn. 2019, 79, 1015-1026. [CrossRef]

82. Žalec, B.; Pavlíková, M. Civic virtues and functions of religion in public life. Eur. J. Sci. Theol. 2019, 15, 75-84.

83. Králik, R.; Roubalová, M.; Slivka, D.; Žalec, B. The ways of bringing first fruits of the land ("bikurim”) into Jerusalem temple: A historical-theological analysis. Hist. Eccles. 2019, 10, 3-15.

84. Univerzita Konštantína Filozofa. Available online: http://www.kgrr.fpv.ukf.sk/en/index.php/component/content/article/10 -novinky / 64-october-14-15-2020-28th-international-geographical-conference (accessed on 8 June 2021).

85. Hašková, A.; Šafranko, C.; Pavlikova, M.; Petrikovičová, L. Application of online teaching tools and aids during corona pandemics. Ad Alta: J. Interdiscip. Res. 2020, 10, 106-112. [CrossRef]

86. Murgaš, F.; Petrovič, F. Quality of life and quality of environment in Czechia in the period of the COVID-19 pandemic. Geogr. Cas. 2020, 72, 261-274. [CrossRef] 